\title{
DUKUNGAN PERILAKU POSITIF OLEH GURU UNTUK MENGURANGI PERILAKU MENGABAIKAN TUGAS PADA SISWA SMA NEGERI 3 BANJARMASIN
}

\author{
Hellya Agustina \\ Jurusan Psikologi Islam Fakultas Ushuluddin dan Humaniora \\ IAIN Antasari Banjarmasin
}

\begin{abstract}
This research aimed to examine positive behavioral support by teacher had been trained to reduce off-task behavior students. The participants of students was second grade of senior high school at Banjarmasin. The reason for using this design was to identifiying behavior target repeatedly with a certain time period. The instruments was be used to take data from observation form positive behavioral support and off-task behavior. The result of analysis data was by using visual analysis and qualitative analysis. From two of analysis indicated that there was different between before and after positive behavioral support implemented by teacher and off-task behavior of two students were reduced into lower frequency.
\end{abstract}

Kata kunci: perilaku positif, guru, tugas, siswa

\section{Pendahuluan}

Sekolah merupakan tempat terbaik bagi sebagian besar anak-anak untuk mempelajari suatu kumpulan pengetahuan dan keterampilan penting tertentu yang harus dipelajari. Fungsi sekolah menurut Sarwono ialah (1) mengembangkan kecerdasan pikiran (perkembangan intelektual) dan memberikan pengetahuan; (2) sebagai lembaga sosial yang khusus di bidang pendidikan dan pengajaran; dan (3) pembentuk suatu nilai karena merupakan masa transisi individu dari rumah ke masyarakat untuk mendapatkan kesempatan melatih diri sendiri dan menjadi individu yang bertanggung jawab sebagai persiapan sebelum terjun ke lingkungan masyarakat. ${ }^{1}$

Menurut penelitian yang pernah dilakukan oleh Central For Public Mental Health, bahwa dunia pendidikan mencakup pula sejumlah stake-holders, yaitu siswa, guru, dan petugas di sekolah yang merupakan salah satu bagian dari sistem yang langsung bersentuhan dengan proses pendidikan. Adanya beban kurikuler dan daya tahan dari anak didik terhadap muatan kurikulum seringkali tidak mempertimbangkan kemampuan siswa. Hal ini menjadikan perkembangan kognitif-sosial yang tidak selaras dan sistem standarisasi mengandung implikasi yang negatif terhadap perkembangan siswa.

Penelitian yang pernah dilakukan oleh Sarwono, dkk menyebutkan bahwa 10,5\% siswa menyatakan cara guru terlalu cepat dalam menjelaskan materi, 1,7\% menyatakan bahwa guru pada saat mengajar sulit untuk dipahami, 22,7\% siswa menyatakan bahwa guru mengajar dengan cara yang tidak menarik, dan 12,2\% siswa menyatakan bahwa selama proses belajar mengajar di dalam kelas cenderung jarang untuk berkomunikasi dan berinteraksi dengan siswanya. ${ }^{2}$

${ }^{1}$ Sarlito Sarwono Wirawan, Psikologi Remaja (Jakarta : Grafindo Utama, 2007), h.124-125.

${ }^{2}$ Sarlito Sarwono Wirawan, Psikologi Remaja, h. 125-126. 
Akan tetapi, yang lebih utama dari permasalahan yang dihadapi oleh siswa adalah metode penyampaian dari para pengajar yang bersifat monoton, tidak ada komunikasi dua arah antara guru dan siswa sehingga membuat siswa menjadi jenuh dan bosan, dan tidak jarang siswa menjadi bolos dan sering tidak melaksanakan tugas yang diberikan kepada mereka. Hal ini menyebabkan siswa melakukan pengabaian tugas.

Pengabaian tugas dapat diartikan bahwa setiap waktu pada saat kegiatan yang dilakukan di dalam kelas siswa tidak mengikuti dengan baik, kurang mampu untuk mengendalikan diri sendiri dengan baik, memperlihatkan perilaku yang tidak sopan terhadap orang lain, dan motivasi dalam melakukan pekerjaan atau tugas sangatlah rendah. Perilaku negatif tersebut dapat berdampak nilai-nilai akademik yang berlaku di suatu kelas. Perilaku ini biasanya direkam dengan menggunakan hasil observasi, observasi guru, dan checklist pada perilaku yang dimaksud. ${ }^{3}$

Pendapat ini diperkuat dengan simptom pengabaian tugas yang dijelaskan oleh Cocea, Hershkovitz, dan Baker di mana perilaku pengabaian tugas ditunjukkan dengan munculnya perilaku atau terlibatnya individu dalam sebuah perilaku lebih dari tiga detik, seperti mengerjakan suatu tugas yang tidak sesuai dengan yang diberikan, berbicara dengan teman pada saat jam pelajaran, berpindah-pindah tempat duduk, dan tidak memperhatikan penjelasan dari guru mengenai tugas yang diberikan. ${ }^{4}$

Salah satu alasan paling umum yang dilakukan oleh sekolah dalam menerapkan dukungan perilaku positif dalam membantu siswa yang sering mengabaikan tugasnya, seperti siswa yang seringkali lalai melaksanakan tugas, mengganggu teman sekelasnya, atau gagal menyelesaikan tugasnya adalah dengan bagaimana cara untuk fokus pada perubahan perilaku dengan memberikan konsekuensi berupa hukuman-hadiah, dan menghilangkan hak istimewa yang dimiliki oleh masing-masing siswa.

Beberapa tahun belakangan ini minat remaja pada hal-hal yang khas berkaitan dengan sekolah dan minat terhadap pelajaran menurun di mana mereka lebih tertarik pada kegiatan yang tidak berhubungan dengan pelajaran sekolah misalnya olahraga dan bermain yang semakin menjadi tidak terkontrol. Fakta tersebut diperkuat dengan pernyataan dari Santrock, bahwa ada kecenderungan individu tidak tertarik pada sekolah, menjadi tidak mau untuk membuat pekerjaan rumah, dan ingin meninggalkan sekolah sesegera mungkin. Di sisi lain, banyak atau sedikitnya minat anak terhadap sekolah dipengaruhi oleh gurunya. Apabila anak membawa konsep yang tidak baik dan tidak positif terhadap guru maka akan memunculkan sikap yang tidak menyenangkan dan cenderung tidak positif terhadap guru. ${ }^{5}$

Selain itu, sebab dari munculnya perilaku negatif pada siswa saat berada di kelas yaitu, bisa diperoleh dari kondisi sosio-ekonomi keluarga, kurikulum yang tidak relevan, sekolah yang terasa sesak karena jumlah siswa melebihi kapasitas kelas, memiliki masalah emosi dan

${ }^{3}$ Edmonson, Flannery, Eber, \& Sugai, April (2005) Revised. Positive Behavior Support in High Schools (Monograph from the 2004 Illinois High School), Forum of Positive Behavioral Interventions and Supports, 1-122, diunduh dari http:// www.pbis.org, h. 2-3.

${ }^{4}$ Cocea, Hershkovitz, \& Baker, (2008), The Impact Of Off-Task And Gaming Behaviors On Learning : Immediate or Aggregate, Procedding of SIGCHI Conference on Human Factors in Computing System, 1-8, h.1-2

${ }^{5}$ Santrock, Remaja (Jakarta: Erlangga, 2006) h. 253-255 
penyesuaian diri, konsep diri yang rendah, kebiasaan untuk membangkang dengan guru, dan menentang kawan sebaya. Hal ini perlu ditangani lebih lanjut salah satunya melalui manajemen kelas yang baik.

Menurut Duke, bahwa dengan adanya ketentuan dan prosedur yang membuat siswa merasa bahwa sekolah adalah tempat yang menyenangkan, dapat menciptakan dan memelihara lingkungan belajar dengan baik sehingga kegiatan belajar mengajar tercipta dengan baik. Di sisi lain, dengan adanya manajemen kelas yang baik dapat memberikan dampak langsung terhadap pencegahan perilaku negatif siswa, seperti mengabaikan tugas, mengganggu teman sekelas lainnya, bolos dari pelajaran, dan lain-lain. ${ }^{6}$

Manajemen kelas yang baik dapat membantu guru dalam menciptakan dukungan dan harapan yang positif dalam kegiatan belajar mengajar yang menyenangkan, siswa memiliki kesempatan untuk lebih banyak mendapatkan apa yang ingin diketahuinya dalam hal mata pelajaran, mengetahui peraturan yang jelas dan masuk akal pada siswa, dan memberikan siswa tanggung jawab atas perilaku dan tugas yang dikerjakannya.

Penelitian yang pernah dilakukan Einsberg menunjukkan bahwa munculnya perilaku yang berkaitan dengan moral dikarenakan adanya pengaruh dari lingkungannya, dengan kata lain bahwa remaja berperilaku agresif sehingga tidak mempunyai tujuan yang jelas saat berada di berbagai situasi karena pengaruh dari lingkungan serta adanya kesenjangan antara pemikiran dan tindakan yang akan dilakukan remaja tersebut. Sebenarnya anak-anak tersebut bukan tidak mengetahui peraturan sekolah, melainkan mereka dengan sengaja melakukan pelanggaran tersebut karena memperoleh sikap yang tidak menyenangkan dari teman sebayanya ataupun gurunya. $^{7}$

Dalam sebuah penelitian yang pernah dilakukan oleh Rowe, dkk untuk mengatasi anakanak yang sering melakukan pengabaian terhadap tugasnya digunakan sebuah teknologi yang pernah dilakukan pada beberapa siswa umur 3-6 tahun dan 7-11 tahun. Rowe, dkk menggunakan teknologi tersebut untuk membuat individu tertarik pada tugas yang dihadapkan padanya, teknologi tersebut menggunakan tutoring sebuah permainan dalam Narrative-Centered Learning Environments (NLEs) yang diberi nama Crystal Island. ${ }^{8}$ Selain itu, ada pula beberapa metode yang pernah dilakukan dalam menangani perilaku mengabaikan tugas (off-task behavior) yaitu, Curriculum Based Assessment (CBA) yang bertujuan untuk mengurangi respon negatif yang sering muncul pada perilaku siswa, Self-managementProgram yang diberikan pada siswa dengan tujuan untuk mengurangi perilaku mengabaikan tugas.

Dalam penelitian Dalton mengenai Self-management Program untuk siswa dengan perilaku mengabaikan tugas digambarkan pada dua orang siswa yaitu Petrus dan Brian yang mengalami kesulitan belajar. Dua orang siswa tersebut ditangani menggunakan program manajemen diri untuk mengurangi perilaku mengabaikan tugas dalam dua kelas yaitu kelas pendidikan umum dan studi ruang kelas. Program pengelolaan diri termasuk dalam tiga komponen yaitu checklist, skala perilaku, dan bentuk pemantauan diri. Hasil penelitian ini menggambarkan keberhasilan

${ }^{6}$ Hasri, Sekolah Efektif dan Guru Efektif (Yogyakarta: Aditya Media Printing and Publishing, 2009), h. 41-42 ${ }^{7}$ Santrock, Remaja, h. 253-255

${ }^{8}$ Rowe, McQuiggan, \& Robinson, Off-Task Behavior In Narrative-Centered Learning Environments, diunduh dari http:/ /www.ncsu.edu, (2008), h.3 
dalam tiga komponen pengaturan diri terjadi perubahan yang cukup signifikan dari awal pelaksanaan sampai dengan proses maintanance program yang diberikan. Pada subjek 1 menunjukkan perubahan yang tinggi dengan menurunnya perilaku mengabaikan tugas menggunakan program self-management yang terdiri dari tiga komponen yang diberikan selama mengikuti pelajaran ilmu pengetahuan 79\%, seni bahasa 87\%, dan LOC 97\%, sedangkan pada subjek 2 menunjukkan perilaku pengabaian tugas dengan menurunkan menggunakan program self-management yang terdiri dari tiga komponen juga mengalami pengubahan perilaku yaitu dalam mengikuti pelajaran ilmu pengetahuan 87\%, ilmu sosial 93\%, dan LOC 84\%. ${ }^{9}$

Metode lain yang pernah digunakan adalah dukungan perilaku positif (positive behavioral support). Dukungan perilaku positif diberikan bertujuan memberikan pengaruh yang bersifat positif pada lingkungan khususnya terhadap siswa-siswa yang memiliki perilaku yang bermasalah, seperti perilaku mengabaikan tugas.

Berdasarkan hasil penelitian Tobin, dkk menyatakan bahwa siswa sekolah menengah atas dengan masalah perilaku yang seringkali terjadi saat berada di sekolah, sehingga disarankan untuk pindah ke sekolah lain karena sering memunculkan perilaku yang negatif terhadap disiplin yang diterapkan oleh sekolah. Instruksi dukungan perilaku positif pernah dilakukan terhadap 15-20 siswa. Dukungan perilaku positif dijadwalkan terhadap 15-20 siswa agar mengikuti intervensi selama beberapa sesi yang akan disampaikan oleh para pelatih. Hal ini dimaksudkan agar para guru dapat secara langsung melatih perilaku yang menjadi harapan sebagai sarana untuk memantau dan mengajarkan perilaku berupa dukungan positif yang sudah diajarkan. Dari awal perilaku diajarkan melibatkan para siswa dan juga para pengajar sehingga dapat dilaksanakan strategi tersebut dan dapat mencapai sebuah harapan bahwa guru dapat memberikan sebuah pengajaran yang menyenangkan. ${ }^{10}$

Dukungan perilaku positif digunakan secara sistematik dan merupakan pendekatan yang dapat memungkinkan sekolah menengah atas untuk lebih efektif menjaga ketertiban sementara waktu dan meminta siswa yang terlibat dalam situasi tersebut untuk menempatkan diri pada resiko yang akan dihadapi sebagai sebuah pengecualian akibat dari munculnya perilaku yang tidak diinginkan. Dukungan perilaku positif juga mengukur sejauh mana harapan dapat didefinisikan, diajarkan, dan diberi penguatan secara positif, melakukan pemantauam melalui sistem dalam menanggapi masalah pelanggaran yang dilakukan oleh siswa, menggunakan data yang didapat selama proses penelitian berlangsung sebagai salah satu pembuat keputusan, dan mengelola kepemimpinan guru yang menjadi salah satu pelaksana administrasi sekolah.

Menurut Horner, Freeman, Nelson, \& Sugai, dukungan perilaku positif mengacu pada aplikasi dari intervensi perilaku positif dan sebuah sistem yang digunakan untuk mencapai perubahan perilaku sosial yang dianggap penting. Adanya dukungan perilaku positif oleh guru dapat memberikan dampak langsung yaitu dalam mencegah muncul perilaku negatif dari siswa, seperti mengabaikan tugas. Ketika guru menggunakan dukungan perilaku positif pada tingkat

${ }^{9}$ Dalton, \& Martella, The Effects of A Self-Management Program In Reducing Off-Task Behavior, Journal of Behavioral Education, 9, 3/4, 157-176, (1999), h.161-162

${ }^{10}$ Tobin, Implementing positive behavior support in regular and alternative high schools: use of the team implementation checklist, Diunduh pada tanggal 25 Maret 2010 dari http://uoregon.edu/ttobin, (2006), h. 2-6. 
kelas, diharapkan mampu menciptakan lingkungan yang positif dan mendorong siswa untuk menjadi peserta yang aktif dalam lingkungan pembelajaran. ${ }^{11}$

Dukungan perilaku positif yang digunakan guru saat berada di ruang kelas, diharapkan mampu untuk menciptakan lingkungan yang positif, mengurangi perilaku mengabaikan tugasnya, dan mendorong siswa untuk menjadi partisipan yang aktif selama proses pembelajaran. Harus ada sebuah perencanaan untuk lingkungan pembelajaran yang dapat mendukung pengembangan keterampilan untuk mencapai suatu kesuksesan akademik dan interaksi sosial saat berada di dalam kelas. Secara singkat, dukungan perilaku positif adalah suatu metode yang digunakan untuk melihat bagaimana lingkungan dapat berperan dalam keberhasilan yang dicapai oleh siswa. ${ }^{12}$

Hal inilah yang melatarbelakangi peneliti untuk memberikan intervensi berupa dukungan perilaku positif kepada siswa melalui pengajar atau guru yang mengajar di kelas agar mereka merasa nyaman dengan sekolahnya, dapat memahami materi dengan mudah yang disajikan oleh para pengajar, dan dapat berkomunikasi secara efektif dengan guru sehingga mampu mengurangi perilaku pengabaian tugas oleh siswa.

\section{Tinjauan Pustaka}

\section{Perilaku Mengabaikan Tugas}

Baker dalam Strout mengungkapkan bahwa salah satu tipe perilaku mengabaikan tugas di mana murid tidak dapat berhubungan dengan lingkungan pembelajaran dan tugas yang seharusnya diikutinya. Lebih lanjut Baker menjelaskan perilaku mengabaikan tugas sering kali dihubungkan dengan tidak suka komputer, matematika, pasif-agresif, dan bukan menjadi siswa yang berprestasi secara akademik. Pola ini mirip dengan pola sikap murid yang memiliki kebiasaan berhubungan dengan siswa yang jarang belajar, yang tidak suka komputer, matematika, dan bukan merupakan pendorong secara akademik.

Rowe menjelaskan lebih lanjut bahwa, perilaku mengabaikan tugas adalah sebuah simptom yang terjadi karena adanya ketidak-bebasan dalam proses belajar-mengajar. Tingginya level dari kebebasan dalam proses belajar adalah hal yang paling penting dalam menyeimbangkan antara motivasi yang dimiliki oleh siswa dengan memaksimalkan pengerjaan tugas yang dilakukan oleh siswa. Salah satu penelitian untuk menangani siswa yang seringkali mengabaikan tugas dengan menggunakan Narrative-centered Learning Environments (NLE's). Sebuah penjabaran (narrative) yang mempunyai tugas untuk menyatukan sepasang mata atau permasalahan yang didapat dari keadaan yang ada di sekeliling orang-orang yang mempunyai kehidupan. Penjabaran tersebut biasanya memberikan sebuah konsep yang tersusun dengan rapi dan memberikan arti dalam sebuah ilmu pengetahuan, pemahaman, dan pengalaman yang sudah didapatkan. NLE's dibedakan kedalam tiga kelompok yaitu berpusat pada penjabarannya (narrative), berpusat pada individu yang memakainya, dan berdasarkan faktor interpersonal individu tersebut. ${ }^{13}$

\footnotetext{
${ }^{11}$ Horner, Freeman, Nelson, \& Sugai, G., Using information in state or district level implementation of school-wide positive behavior interventions and supports, Journal of Positive Behavior Intervention and Support, 2, 2, Diunduh dari http://www.pbis.org/ volume 2/issue2.aspx, (2000), h.1

${ }^{12}$ Strout, Considerations and strategies at the classroom level, Journal of Positive Behavior, 3, 3-8, (2005), h.1-2

${ }^{13}$ Rowe, Off-Task Behavior, h.1-2
} 
Menurut Cocea, dkk, tipe perilaku mengabaikan tugas adalah: (a) berbicara dengan murid lain tentang topik yang tidak relevan dengan pelajaran; (b) sering mencari-cari sesuatu hal yang menyenangkan lewat jejaring sosial; dan (c) senang menganggu murid lainnya. ${ }^{14}$

Menurut Dalton, karakteristik perilaku mengabaikan tugas, adalah gagal untuk mengikuti petunjuk guru, meninggalkan kursi, menggoda dan melecehkan siswa lain, tidak berpartisipasi dalam penugasan yang diberikan, berdebat dengan guru dan teman sebayanya, dan membuat suara-suara mengganggu, gerakan, dan komentar di kelas. ${ }^{15}$

Menurut Coyle, persyaratan untuk perilaku yang dianggap sebagai perilaku mengerjakan tugas adalah : (a) duduk selama sesi tugas mandiri; (b) mampu memperlihatkan hasil tugasnya dan memelihara keterlibatan dan konsentrasi pada tugas yang ditunjuk; (c) selama masa kerja mandiri, dia diminta untuk menahan diri dari menyentuh setiap objek lain selain materi yang berhubungan dengan pekerjaan; dan (d) mampu menahan diri dari bermain dengan bagian tubuh pribadi atau lainnya objek yang tidak terkait.

Caldwell, dkk mengungkapkan bahwa seseorang yang memunculkan perilaku melakukan tugas memiliki ciri-ciri sebagai berikut: (a) tepat waktu dalam menyelesaikan tugas; (b) presentase melengkapi tugas tinggi; (c) persentase melengkapi tugas dengan benar. ${ }^{16}$

Berdasarkan teori di atas dapat disimpulkan bahwa perilaku mengabaikan tugas adalah perilaku yang muncul karena adanya ketidak-bebasan dalam proses belajar-mengajar yang ditunjukkan melalui aktivitas sebagai berikut:

a. Mengganggu murid lain pada saat pelajaran berlangsung;

b. tidak aktif dalam mengerjakan tugas;

c. gagal mengikuti petunjuk guru;

d. membolak-balik kertas disebabkan saat guru menjelaskan tugas siswa tidak memahami dengan baik;

e. mencoret-coret buku atau kertas, yang tidak ada hubungannya dengan mata pelajaran.

Penelitian lain yang pernah dilakukan oleh Center for Effective Collaboration and Practice menunjukkan bahwa penyebab siswa berperilaku mengabaikan tugas yaitu, merasa malu saat diminta oleh gurunya untuk membaca keras-keras di depan, merasa frustasi saat menghadapi masalah akademik dan sosial di dalam kelas, merasa bosan dengan bidang akademik sehingga menganggap terlalu mudah, dan kurang mampu dalam mengontrol perilaku yang negatif saat berada di kelas.

Dapat disimpulkan bahwa faktor penyebab siswa mengabaikan tugas adalah cara guru mengajar yang dinilai siswa tidak menarik dan sulit dipahami, adanya label dari guru seperti nakal, bodoh, pemalas, rasa bosan selama pelajaran karena guru mengajar terlalu cepat dan siswa tidak mengerti apa manfaat materi yang disajikan dalam kehidupan sehari-hari, dan tidak ada komunikasi dua arah antara guru dan siswa saat proses belajar-mengajar.

${ }^{14}$ Cocea, The impact of off-task, h.1-2

${ }^{15}$ Dalton, \& Martella, The Effects of A Self-Management, (1999), h. 1-2

${ }^{16}$ Caldwell, The Effects of A Self-Management Procedure on The On-Task Behavior, academic productivity, and academic accuracy of female students with disabilities in a juvenile correctional high school setting, Dissertation Graduate Program in Education and Human Ecology, (The Ohio State University, 2010), h. 19-20 


\section{Dukungan Perilaku Positif}

Perilaku bukan sebuah ilmu pengetahuan mengenai perilaku manusia akan tetapi merupakan filosofi dari ilmu pengetahuan tersebut. Perilaku manusia merupakan hal yang paling istimewa di dunia tempat dimana tiap individu tinggal dan melakukan aktivitas lainnya. Prinsip-prinsip perilaku dapat membantu dalam mengatasi masalah perilaku yang sulit.Ada tiga pendekatan yang saling terkait secara khusus untuk perilaku-perilaku yang menantang yaitu, penerapan analisis perilaku terapan, analisis fungsional, dan dukungan perilaku positif. ${ }^{17}$

Sekelompok prosedur yang secara sistematis menerapkan prinsip-prinsip perilaku dikenal sebagai Penerapan Analisis Perilaku (Applied Behavior Analysis ABA) juga dikenal dengan istilah modifikasi perilaku. Penerapan analisis perilaku didasarkan pada asumsi bahwa:

a. masalah perilaku disebabkan oleh kondisi lingkungan masa lalu dan sekarang; dan bahwa

b. memodifikasikan lingkungan siswa saat ini yang akan mendorong respons-respons yang lebih produktif.

Analisis perilaku terapan bertujuan untuk membantu siswa menjalankan perilaku yang lebih tepat di kelas, biasanya digunakan strategi sebagai berikut:

a. mendeskripsikan baik perilaku saat ini maupun perilaku akhir yang diinginkan dalam istilah yang dapat diamat dan diukur;

b. mengidentifikasi satu atau lebih penguat yang lebih efektif;

c. mengembangkan intervensi spesifik atau rencana penanganan (treatment), yang bisa melibatkan penguatan terhadap perilaku yang diinginkan, pembentukan, ekstinksi, penguatan terhadap perilaku yang berlawanan, hukuman, atau kombinasi hal-hal tersebut;

d. mengukur frekuensi perilaku yang diinginkan dan yang tidak diinginkan baik sebelum diberikan penanganan (yaitu pada tingkat baseline) maupun selama diberikan penanganan;

e. melakukan monitor program penanganan demi keefektifan dalam mengamati bagaimana berbagai perilaku berubah seiring waktu dan memodifikasi program tersebut jika diperlukan;

f. mengambil langkah-langkah untuk mendorong generalisasi terhadap perilaku yang baru diperoleh (misalnya, dengan meminta siswa tersebut menjalankan perilaku tersebut dalam berbagai situasi nyata);

g. secara bertahap mengurangi penanganan tersebut setelah perilaku yang diinginkan diperoleh.

Ratusan studi penelitian mengenai perilaku memberitahu bahwa dengan menggunakan prinsip-prinsip perilaku secara sistematis dapat membawa perbaikan yang signifikan untuk meningkatkan prestasi akademik dan perilaku di kelas. Ketika memberikan penguatan pada perilaku yang sesuai saat berada di kelas dengan cara menaruh perhatian, berinteraksi secara kooperatif dan prososial dengan teman-temannya sehingga perilaku yang tidak sesuai menjadi menurun.

Dukungan perilaku positif adalah berbagai strategi yang secara sistemik dan individual untuk mencapai perilaku sosial yang penting dan sebagai hasil sementara dari pembelajaran

${ }^{17}$ Ormrod, Psikologi Pendidikan Membantu Siswa Tumbub Dan Berkembang Edisi Keenam, jilid 1, (Jakarta: Erlangga, 2008). h. $461-465$ 
untuk mencegah munculnya masalah perilaku. Menurut Horner yang didukung juga oleh Lewis, Sugai, dkk menyatakan bahwa kunci penting dalam dukungan perilaku positif adalah meliputi proaktif, cara pengambilan keputusan, sampai dengan orientasi pemecahan masalah. Dukungan perilaku positif tidak hanya fokus terhadap permasalahan perilaku dalam ranah klinis akan tetapi menekankan gaya hidup yang fokus dan berkesinambungan yang dilakukan oleh guru, keluarga, dan juga orang lain yang terlibat dalam dukungan tersebut. ${ }^{18}$

Proses dukungan perilaku positif ditandai sebagai suatu pemecahan masalah dan proses merencanakan sebuah aksi dimana sekolah

a. meninjau data mengenai permasalahan yang ada di sekolah;

b. mengembangkan suatu tujuan yang bisa diukur dan memberikan hasil yang realistik dalam jangka panjang;

c. memilih praktek secara dapat sehingga dapat menunjukkan suatu keberhasilan dalam mencapai hasil yang diinginkan; dan

d. membangun suatu sistem yang mungkin dapat diadaptasi sehingga bisa digunakan secara efektif, efisien, dan relevan dengan kondisi yang ada. ${ }^{19}$

Menurut teori yang telah dijelaskan mengenai dukungan perilaku positif dapat disimpulkan bahwa dukungan perilaku positif adalah sebuah strategi yang secara efektif dapat membantu guru dalam menangani siswa dengan perilaku mengabaikan tugas melalui:

a. modifikasi lingkungan kelas dengan cara menata kembali kursi dan meja beserta peralatan lain yang ada di kelas;

b. memberikan rasa nyaman dan aman selama berada di kelas;

c. membuat penyesuaian proses mengajar;

d. menumbuhkan affirmasi positif sehingga tidak muncul perilaku yang tidak diinginkan;

e. memberikan siswa kesempatan untuk memilih mengenai metode pengajaran guru sehingga tidak muncul perilaku yang tidak diinginkan;

f. mengevaluasi semua strategi yang sudah diberikan kepada guru.

Secara khusus, dukungan perilaku positif melibatkan strategi sebagai berikut :

a. mengajarkan perilaku yang dapat membentuk maksud yang sama atau dapat menggantikan perilaku yang tidak sesuai dengan yang lebih sesuai;

b. memodifikasi lingkungan kelas untuk meminimalisasi kondisi-kondisi yang bisa memicu munculnya perilaku yang tidak sesuai;

c. membangun kebiasaan sehari-hari sebagai cara meminimalisasi kecemasan dan membuat siswa merasa lebih nyaman dan aman;

d. memberikan siswa kesempatan membuat pilihan, dengan cara seperti ini biasanya siswa mampu mendapatkan hasil yang diinginkan tanpa terlibat dalam perilaku yang tidak sesuai;

e. membuat penyesuaian-penyesuaian dalam kurikulum pengajaran, proses belajar-mengajar, atau keduanya untuk memaksimalkan kemungkinan siswa sukses dalam bidang akademik;

${ }^{18}$ Edmonson, Flannery, Eber, \& Sugai, April (2005) Revised. Positive behavior support in high schools : (Monograph from the 2004 Illinois High School), Forum of Positive Behavioral Interventions and Supports, 1-122, diunduh dari http:// www.pbis.org., h. 1

${ }^{19}$ Horner, Freeman, Nelson, \& Sugai, G, Using information, h. 1 
f. memonitor frekuensi munculnya berbagai perilaku untuk menentukan apakah intervensi yang dilakukan berjalan dengan baik atau sebaliknya memerlukan modifikasi (Ormrod, 2008).

Dukungan Perilaku Positif mengandung elemen teori perilaku, termasuk fokus dalam membentuk lingkungan yang memberi penguatan pada perilaku yang diinginkan dan menghilangkan perilaku yang tidak diinginkan. Dukungan Perilaku Positif juga memasukkan teori kontemporer dalam hal motivasi, sebagaimana hal-hal dalam mengurangi kecemasan, menyediakan kesempatan untuk membuat pilihan, dan mendorong penguasaan terhadap tugastugas kelas.

Dukungan perilaku positif mengacu pada penerapan intervensi perilaku positif dan sistem untuk mencapai hal yang bersifat sosial yang penting dalam perubahan perilaku. ${ }^{20}$ Ketika menggunakan dukungan perilaku positif pada tingkat kelas, hal ini diharapkan mampu untuk menciptakan lingkungan yang positif dan mendorong siswa untuk menjadi peserta aktif dalam mereka belajar.'Terlebih dahulu harus merencanakan untuk lingkungan belajar yang mendukung pengembangan keterampilan yang dapat meningkatkan kesuksesan akademik dan interaksi sosial di dalam kelas. Dengan kata lain, bahwa dukungan perilaku positif adalah sebuah metode mempertimbangkan bagaimana lingkungan bisa membuat lebih mungkin bagi semua siswa untuk sukses.

Dapat disimpulkan bahwa dukungan perilaku positif adalah sebuah strategi yang secara efektif dapat membantu guru dalam menangani siswa dengan perilaku mengabaikan tugas.

\section{Metode Penelitian}

Penelitian ini merupakan penelitian kuasi eksperimen. Desain yang digunakan dalam penelitian ini adalah single subject design, yaitu bagian dari desain eksperimen yang mengukur variabel terikat atau target perilaku yang dilakukan secara berulang-ulang dengan periode waktu tertentu misalnya, perjam, perhari, atau perminggu. Perbandingan dilakukan pada subjek yang sama dalam waktu yang berbeda, yaitu kondisi baseline atau kondisi di mana pengukuran target perilaku dilakukan pada keadaan sebelum diberikan intervensi apapun, dan kondisi intervensi dimana suatu intervensi diberikan dan target perilaku diukur di bawah kondisi tersebut. ${ }^{21}$

Pada penelitian single subject design selalu dilakukan perbandingan antara kondisi baseline dengan sekurang-kurangnya satu kondisi intervensi. Desain untuk single subject design pada penelitian ini adalah :

\section{$\mathrm{O} 1 \mathrm{O} 2 \mathrm{O} 3 \mathrm{O} 4 \mathrm{O} 5 \rightarrow \mathrm{x} \rightarrow \mathrm{O} 6 \mathrm{O} 7 \mathrm{O} 8 \mathrm{O} 9$}

Gambar 2. Desain Eksperimen Single Subject Design

O1-5 : Kondisi Baseline sebelum diberikan intervensi yaitu Perilaku Mengabaikan Tugas

${ }^{20}$ Horner, Freeman, Nelson, \& Sugai, G, Using information, h. 2

${ }^{21}$ Sunanto, Takeuchi, \& Nakata, Pengantar Penelitian Dengan Subyek Tunggal, (Criced: University of Tsukuba, 2005) h. 54-55 
X : Intervensi berupa Program tentang Dukungan Perilaku

Positif yang diberikan selama 2 hari

O6-9 : Kondisi setelah diberikan intervensi yaitu berkurangnya

Perilaku Mengabaikan Tugas

Alasan menggunakan desain $\mathrm{O} \rightarrow \mathrm{X} \rightarrow \mathrm{O}$ pada penelitian kuasi eksperimen berikut ini dibandingkan desain yang lain adalah dapat mendefinisikan target perilaku sebagai suatu perilaku yang dapat diukur secara akurat, mengukur dan mengumpulkan data pada kondisi baseline (O1) secara berulang-ulang sekurang-kurangnya 3 atau 5 kali sampai trend dan level data menjadi stabil menurut peneliti, memberikan intervensi setelah trend data baseline stabil, mengukur dan mengumpulkan data pada fase intervensi $(\mathrm{X})$ dengan periode waktu tertentu sampai data menjadi stabil, dan setelah trend dan level data pada fase intervensi (X) stabil maka dilakukan pengukuran pada fase setelah intervensi $(\mathrm{O} 2)^{22}$

Analisa hasil penelitian dijelaskan melalui analisa visual dan analisa kualitatif. Hasilnya dijelaskan sebagai berikut :

\section{Analisa Visual}

\section{a. Guru}

Pada tahap pertama yaitu diterapkan dukungan perilaku positif berdasarkan hasil observasi dengan menggunakan analisa visual diperoleh hasil sebagai berikut :

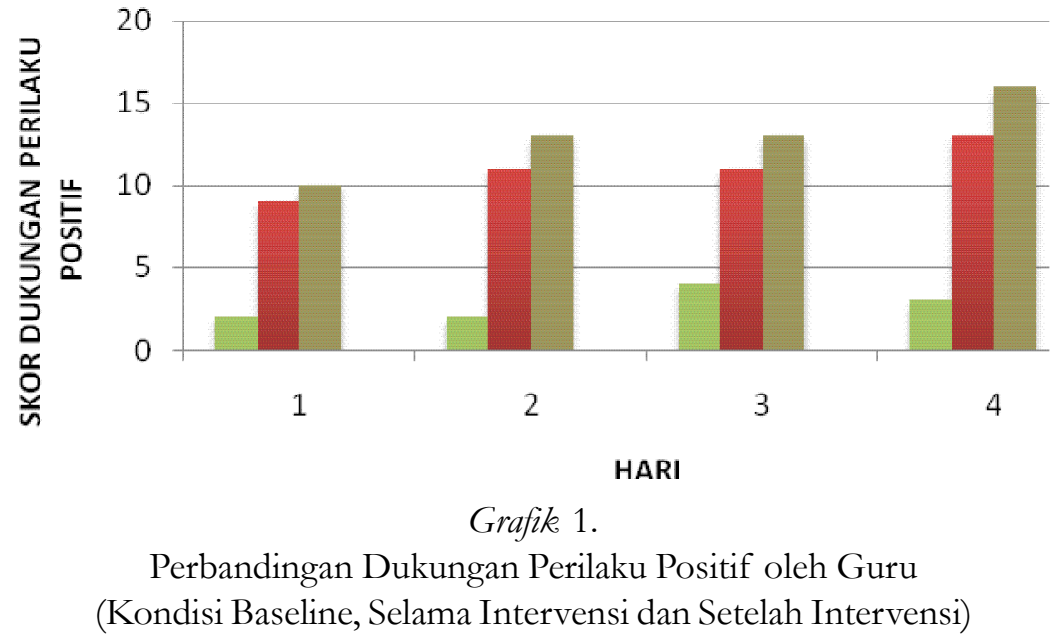

\section{Keterangan :}

Hijau : Kondisi Baseline

Merah : Kondisi Selama Intervensi (berupa pelatihan pada guru)

Cokelat : Kondisi Setelah Intervensi

Pada grafik 1 terlihat ada perbedaan dukungan perilaku positif yang diberikan oleh guru pada kondisi baseline saat guru masih belum dilatih mengenai dukungan perilaku positif, kondisi

\footnotetext{
${ }^{22}$ Barlow, \& Hersen, Single Case Experimental Designs : Strategies For Studying Behavior Change, (United States of America: Pergamon Press, 1984), h.140-142
} 
selama intervensi saat guru menerapkan dukungan perilaku positif setelah sebelumnya dilatih oleh psikolog mengenai dukungan perilaku positif, dan kondisi setelah intervensi saat guru sudah menerapkan dukungan perilaku positif kemudian dievaluasi. Hal ini dikatakan bahwa guru sudah menerapkan dukungan perilaku postif sebagai upaya untuk mengurangi perilaku mengabaikan tugas pada subjek $\mathrm{P}$ dan $\mathrm{L}$, dan juga bertambahnya pengetahuan guru mengenai dukungan perilaku positif sebagai salah satu intervensi dalam mengurangi perilaku mengabaikan tugas pada siswa.

\section{b. Siswa}

Pada tahap kedua, siswa yang berperilaku mengabaikan tugas agar perilakunya berkurang akan diterapkan dukungan perilaku positif yang dilakukan oleh guru selama mata pelajaran Matematika berlangsung. Adapun hasil observasi pada subjek P dan L selama guru menerapkan dukungan perilaku positif dalam upaya mengurangi perilaku mengabaikan tugasnya, menggunakan analisa visual diperoleh hasil sebagai berikut :

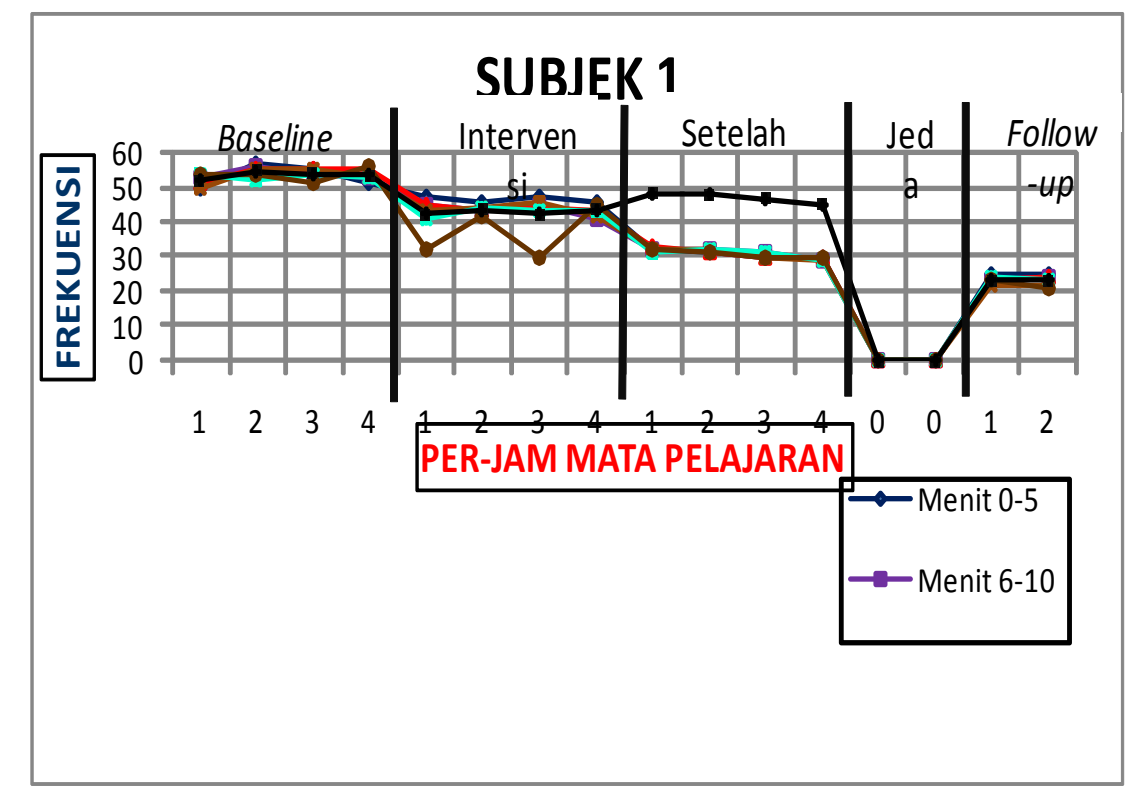

\section{Analisa Kualitatif}

Analisa kualitatif dilakukan berdasarkan data yang diperoleh dari skor frekuensi perilaku mengabaikan tugas (off-task behavior) oleh pengamat dan wawancara dengan guru. Pencatatan kualitatif melalui observasi dilakukan mulai dari kondisi baseline selama dua hari atau 4 jam mata pelajaran Matematika berlangsung. Secara umum perilaku yang frekuensinya banyak muncul saat 4 jam mata pelajaran Matematika berlangsung adalah berpindah tempat duduk, berbicara saat mata pelajaran berlangsung, melempar sesuatu ke arah teman, berjalan-jalan di kelas, masuk kelas terlambat, tidak mengerjakan tugas yang diberikan oleh guru selama mata pelajaran berlangsung, berdebat tentang sesuatu yang tidak ada hubungannya dengan mata pelajaran, tidak membawa buku catatan, mengerjakan tugas mata pelajaran lainnya, melihat pekerjaan teman saat berada di kelas. 
Setelah intervensi yaitu kondisi follow-up dengan jeda satu hari, berdasarkan hasil observasi dari beberapa perilaku dalam 20 indikator perilaku mengabaikan tugas ada beberapa perilaku yang sudah tidak muncul lagi pada kedua subjek yang diobservasi.

\section{Penutup}

Program "Dukungan Perilaku Positif oleh Guru" salah satu program yang dinilai efektif untuk mengurangi perilaku mengabaikan tugas pada siswa. Ditahap pertama guru dilatih untuk menerapkan dukungan perilaku positif pada siswa yang berperilaku mengabaikan tugas. Dari indikator dukungan perilaku positif guru mengalami peningkatan dalam penerapan selama di kelas sebagai upaya mengurangi perilaku mengabaikan pada siswa selama pelajaran berlangsung. Berkurangnya perilaku mengabaikan tugas pada siswa dibuktikan dari 20 indikator, beberapa diantaranya frekuensi kemunculan perilaku mengabaikan tugas sudah berkurang dan ada yang tidak muncul lagi. Dukungan perilaku positif tidak hanya dapat diterapkan selama intervensi tetapi juga bisa diterapkan secara terus menerus selama proses belajar-mengajar berlangsung sehingga perilaku mengabaikan tugas pada dua orang siswa tidak terulang kembali.

\section{DAFTAR PUSTAKA}

Barlow, D. H., \& Hersen, M. (1984). Single Case Experimental Designs : Strategies For Studying Behavior Change. United States of America : Pergamon Press

Campbell, D. T., \& Stanley.J.C. (1966). Experimental And quasi-experimental designs for research. United States of America : Library of Congress Catalogue

Caldwell, S. L. (2010). The Effects Of A Self-Management Procedure On The On-Task Behavior, Academic Productivity, And Academic Accuracy Of Female Students With Disabilities In A Juvenile Correctional High School Setting. Dissertation Graduate Program in Education and Human Ecology. The Ohio State University

Cocea, M., Hershkovitz, A., \& Baker, R. S. J. D. (2008). The Impact Of Off-Task And Gaming Behaviors On Learning: Immediate Or Aggregate. Procedding of SIGCHI Conference on Human Factors in Computing System, 1-8.

Cook, T. D., \& Campbell, D. T. (1979). Quasi experimentation design and analysis issues for field settings. Boston: Houghton Mifflin Company

Dalton, T., \& Martella. R. C. (1999). The Effects Of A Self-Management Program In Reducing OffTask Behavior. Journal of Behavioral Education

Edmonson, H. K., Flannery, K. B., Eber, L., \& Sugai, G. (2005). Positive behavior support in high schools: (Monograph from the 2004 Illinois High School). Forum of Positive Behavioral Interventions and Supports, Diunduh dari http://www.pbis.org

Hasri, S. (2009). Sekolah Efektif Dan Guru Efektif. Yogyakarta : Aditya Media Printing and Publishing

Horner, R., Freeman, R., Nelson, C. M., \& Sugai, G. (2000). Using Information In State Or District Level Implementation Of School-Wide Positive Behavior Interventions And Supports. Journal of Positive Behavior Intervention and Support, Diunduh dari http:// www.pbis.org/volume 2/issue2.aspx. 
Miles, M. B., \& Huberman, A.M. (2009). Analisis Data Kualitatif Terjemahan tjejep rohendi rohidi. Jakarta: UI Press

Ormrod, J. E. (2008). Psikologi Pendidikan Membantu Siswa Tumbub Dan Berkembang, edisi keenam jilid 1. Jakarta: Erlangga

Roberts, M. (2008). Off-Task Behavior In The Classroom: Applying FBA and CBM. University of Oregon

Rowe, P. J., McQuiggan, S.W., \& Robinson, J.L. (2008). Off-Task Behavior In Narrative-Centered Learning Environments. Diunduh dari http://www.ncsu.edu

Santrock, J. W. (2006). Remaja. Jakarta : Erlangga

Shadish, W. R., Cook, T. D., \& Campbell, D. T. (2002). Experimental And Quasi-Experimental Designs For Generalized Causal Inference. New York : Houghton Mifflin Company

Strout, M. (2005). Considerations and strategies at the classroom level. Journal of Positive Behavior, 3, 38

Sunanto, J., Takeuchi, K., \& Nakata, H. (2005). Pengantar Penelitian Dengan Subyek Tunggal. Criced: University of Tsukuba

Tobin, T. J. (2006). Implementing Positive Behavior Support In Regular And Alternative High Schools : Use Of The Team Implementation Checklist. Diunduh pada tanggal 25 Maret 2010 dari http://uoregon.edu/ttobin 